\title{
Investigation into sanitation options for rural Kien Giang Province, Vietnam
}

\author{
Tracey Main \\ Department of Environmental Engineering, RMIT University, Melbourne Australia \\ and Returned Field Volunteer, Engineers Without Borders Australia, Melbourne \\ Tracey.Main.TM@gmail.com
}

\begin{abstract}
This project was developed during a three month internship with Habitat for Humanity Vietnam (HFHV) supported by the Royal Melbourne Institute of Technology (RMIT) Engineers Without Borders Australia (EWB) Development Scholarship for 2010/2011. During discussions with HFHV staff, several areas of concern with regards to sanitation and hygiene practices in rural Kien Giang Province were raised. These included the widespread use of drop toilets over waterways, poor hygiene practices in impoverished households and in schools, lack of sanitation options for HFHV construction programmes and no facilities for emptying existing septic tanks of accumulated sludge. This article evaluates existing sanitation technologies for introduction into HFHV's construction programme in Kien Giang Province. It was determined that for onsite disposal of sanitation system products, the double dehydration vault, the composting chamber and the urine collection tank were appropriate technologies. Pit latrines or variations thereof were deemed inappropriate because of the high watertables. Anaerobic reactor systems were deemed inappropriate as they accumulate pathogenic sludge and effluent for which there is currently no appropriate treatment that meets the project design criteria. As onsite disposal system demand may be low due to cultural and social taboos, an investigation and discussion into offsite treatment was also undertaken. It was determined that a co-composting facility would be the most appropriate offsite treatment technology.
\end{abstract}

KEYWORDS: Composting, dehydration vaults, EcoSan, high watertable, rural, sanitation.

\section{INTRODUCTION}

\subsection{Background}

Approximately 2.6 billion people or 39 percent of the world's population live without access to improved sanitation (WHO, 2010). Sanitation problems are an issue that affects the world's poorest. Black \& Fawcett (2008) state that it is no coincidence that the number of people without access to improved sanitation is almost equivalent to those living on less than US\$2.00 per day.

Table 1 displays data for access to improved water and sanitation for both rural and urban populations in Vietnam as compiled by the Institute for Sustainable Futures (ISF). One of the difficulties of sanitation data is the inconsistency of the data and in this case results range from 41 per cent to 66 per cent of people with access to improved sanitation. The differences in data often relate to differing definitions of what constitutes improved sanitation.

Regardless of which set of data is used, these figures obscure the sanitation problem in Vietnam. A figure of even 41 per cent seems relatively good in comparison to Vietnam's neighbour Cambodia, whose rural population with access to improved sanitation is around 23 per cent. However, Vietnam is the world's thirteenth most populous country with around 89 million people. In addition, around 70 per cent of the population lives in rural areas. This means that, even taking the most conservative figure of 66 per cent, around 21 million people in rural Vietnam do not have access to improved sanitation. In terms of the number of people without access to improved sanitation this is roughly double that in Cambodia (IFS-UTS, 2011). 
Table 1: $\quad$ Access to improved sanitation in Vietnam (ISF-UTS, 2011).

\begin{tabular}{|c|c|c|c|c|c|}
\hline \multicolumn{2}{|c|}{ Data source } & $\begin{array}{c}\text { Vietnam } \\
\text { General } \\
\text { Statistical Office } \\
\text { Population and } \\
\text { AIDS Indicator } \\
\text { Survey }\end{array}$ & $\begin{array}{c}\text { WHO/UNICEF } \\
\text { JMP }\end{array}$ & $\begin{array}{c}\text { Vietnam } \\
\text { National Target } \\
\text { Program - } \\
\text { access based } \\
\text { on Ministry } \\
\text { of Health } \\
\text { standards } \\
\end{array}$ & $\begin{array}{l}\text { Vietnam } \\
\text { Ministry of } \\
\text { Agriculture } \\
\text { and Rural } \\
\text { Development }\end{array}$ \\
\hline \multicolumn{2}{|l|}{ Year } & 2005 & 2008 & 2010 & 2011 \\
\hline \multirow[t]{2}{*}{ Water } & Urban & & $99 \%$ & & \\
\hline & Rural & & $92 \%$ & $42 \%$ & $75 \%$ \\
\hline \multirow[t]{2}{*}{ Sanitation } & Urban & \multirow{2}{*}{$41 \%$} & $94 \%$ & & \\
\hline & Rural & & $66 \%$ & $60 \%$ & $52 \%$ \\
\hline
\end{tabular}

\subsection{The physical environment}

Kien Giang Province is located in the South West of Vietnam and lies within the Mekong River delta. The climate is tropical monsoon with two seasons; the wet season from May to November and the dry season from December to April. The area receives around 2,200 mm of rainfall per annum, of which 90 per cent falls during the wet season (HFHVa, 2012).

The topography is mainly low lying marshy flatlands with estuaries and river floodplains. In general, the land slopes from the northeast to the southwest of the province with the northeast having an average elevation of one metre above sea level and the southwest, 0.3 metres above sea level. Soils in the area are mostly river or marine sediments with clay percentages ranging from $45-58$ per cent (Le, 2011).

The hydrology in the Province is affected by the Mekong River system, rains and tidal movement in coastal areas. The flooding season occurs from July to November with peak flood levels in October (Le, 2011). The hydrology is controlled by an extensive network of canals that transport water throughout the Province to facilitate rice cropping, drainage, water storage and transport. Long lasting and deep floods are not considered significant problems by Provincial authorities because of the agricultural use of land in the Province (Mackay \& Russell, 2011).
Houses in the province are mainly situated along the canals and rivers with rice paddies in the centre. There are few roads in the Province with the capacity to carry cars and trucks; two north-south roads linking coastal centres (NR80 and NR63) and one heading east towards Can Tho (NR61) (Mackay \& Russell, 2011).

The few remaining roads cater for motorbikes and pushbikes and are only wide enough to allow for two motorbikes to pass each other. Canal crossings are usually by narrow bridge for motorbikes, footbridges or by ferry crossings (Figure 1). Transport of goods is either by road to population centres or by boat in other areas. "Water transport is a key means of access through channels into rural areas where there are few roads" (Mackay \& Russell, 2011).

\subsection{Existing sanitation technologies in rural Kien Giang}

One of the most common sanitation technologies used in rural Kien Giang Province is the drop toilet over a waterway which generally consists of a small covered, walled superstructure with a hole in the floor through which urine and faeces fall directly into the water (Figure 2). The water receiving the waste becomes heavily polluted and people downstream of the latrine are exposed to pathogens (ITN-Bangladesh, 2003). The Government has made
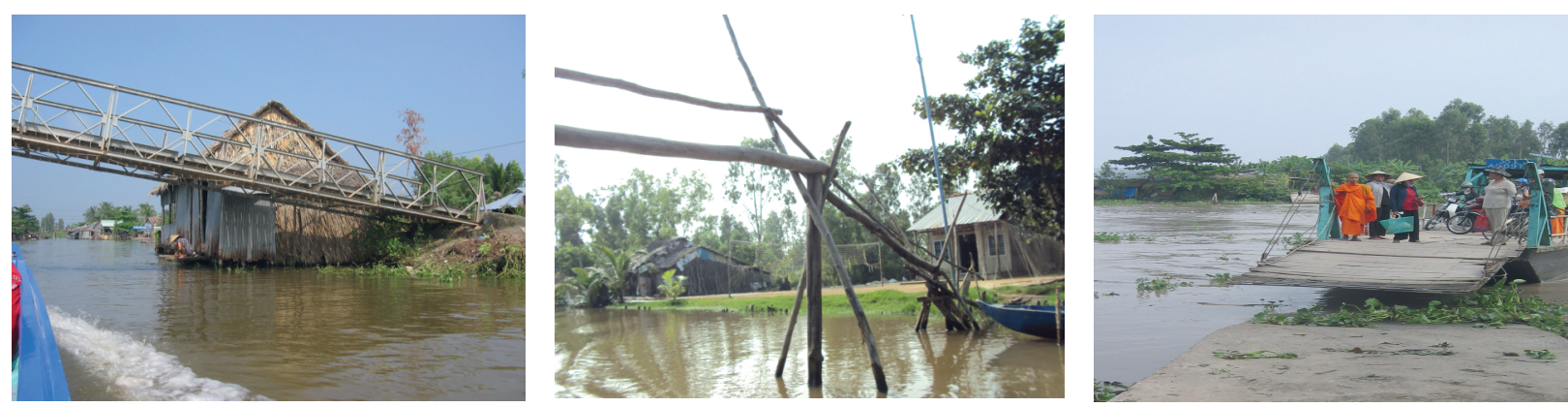

Figure 1: Crossing waterways - motorbike bridge (left), footbridge or "monkey bridge" (middle) and small ferry crossing (right). 

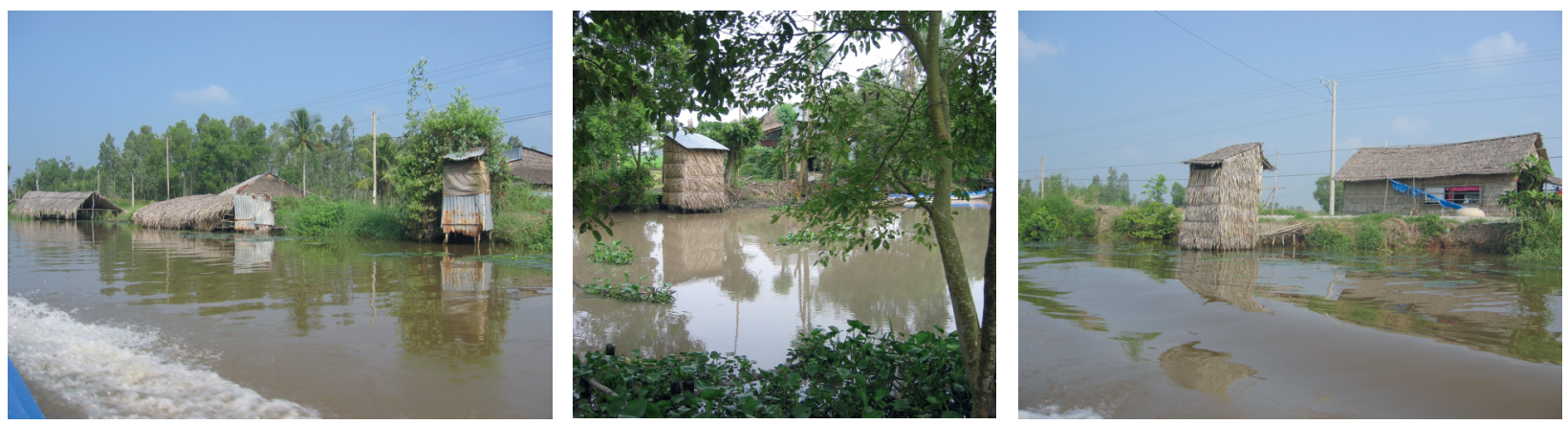

Figure 2: Drop toilets in rural Kien Giang Province.

the installation of new drop toilets illegal in an effort to phase them out (HFHVb, 2012).

HFHV have advised that, for rural areas of Kien Giang, there are currently no facilities for the collection and centralised treatment of sanitation waste products. If drop toilets are phased out and people are forced to install toilets that collect waste onsite, there will be no option for the collection and disposal of the waste offsite. Waste could be treated and disposed of onsite; however, this will depend on acceptance of these technologies. If onsite disposal and drop toilets become unacceptable then people may revert to sanitation behaviours less desirable than the current situation.

\subsection{Considerations for sanitation programs}

If people are required to install a toilet in their home to collect excrement then there must also be a way for them to safely dispose of the system's products. If there is no disposal method implemented from the beginning, the project will fail. System products will build up onsite until the technology breaks-down (the pit becomes too full or the septic tank fills with sludge). This may cause the householders to abandon the technology and go back to previous habits, such as the use of drop toilets.

Sanitation systems can be broken down into onsite systems or offsite systems (ITN-Bangladesh, 2003). For the purpose of the project, an onsite system includes the collection, treatment and disposal of human waste on the householder's land. Offsite systems require the transportation of the system's products from the household for further treatment and disposal or reuse.

Onsite disposal of sanitation system products depends on the social and cultural acceptance of disposing of human waste on the householders' own land. Although there are benefits to doing so, the social stigma or cultural beliefs attached to onsite use may be a sufficient deterrent to prohibit the technology's uptake. Education on the benefits of onsite use may reduce these impacts and improve uptake of onsite disposal technologies.

For onsite disposal of products, there also needs to be a use for the nutrients contained in the products. If the household does not have a garden, aquaculture pond or other facility requiring the nutrients, the urine, dehydrated faeces, effluent or compost will not be desirable and will become a burden requiring disposal. Homes without a reason for onsite disposal will either need collection facilities and offsite treatment or a neighbour that does have a use for the products and who is willing to take them. Without either of these two options current defecation practices are likely to continue for these households. For households that do have a use for the nutrients, onsite disposal can provide beneficial use, improving soils and providing nutrients to offset chemical fertiliser use.

Table 2: Design criteria.

\begin{tabular}{|l|l|}
\hline Necessary Criteria & Desirable Criteria \\
\hline $\begin{array}{l}\text { Isolates pathogenic products from human contact } \\
\text { in high water table and flood prone environments }\end{array}$ & $\begin{array}{l}\text { Complement HFHV's existing housing design } \\
\text { or sanitation system construction }\end{array}$ \\
\hline Suitable for clay soil environments & Constructed using local materials \\
\hline Is culturally acceptable & Cost no more than US\$300 for a single household \\
\hline Designed for a single household & \\
\hline Proven and ready for HFHV to implement & \\
\hline Minimal ongoing expenses & \\
\hline
\end{tabular}




\section{METHODOLOGY}

Appropriate sanitation options for rural Kien Giang Province were identified by evaluating sanitation technologies listed in two publications against environmental conditions and the design criteria listed in Table 2.

The publications utilised were The Compendium of Sanitation Systems and Technologies published in 2008 by the Swiss Federal Institute of Aquatic Science and Technology (EAWAG), and Sanitation Strategies and Technologies: Flood-prone and High Water Table Areas of Bangladesh published in 2003 by ITNBangladesh. These publications were used as all of the technologies within these publications have been proven and are in use as sanitation options.

As there is no offsite collection or treatment facilities available in rural Kien Giang and as HFHV does not implement or construct these, all technologies within the publications requiring offsite collection or treatment were immediately determined as inappropriate for the project and were not evaluated further.
Onsite sanitation technologies were evaluated against the environmental conditions. These conditions cannot be changed and the technology needs to be able to work within them.

Lastly, the technologies were evaluated against the remaining necessary criteria, being culturally acceptable and having minimum ongoing expenses, and the three desirable criteria.

\section{EVALUATION \& DISCUSSION}

\subsection{Evaluation against the necessary design criteria}

Table 3 contains a list of the onsite storage and treatment technologies from the Compendium of Sanitation Systems and Technologies and Sanitation Strategies and Technologies: Flood-prone and High Water Table Areas of Bangladesh. Table 3 displays the technology's evaluation against the necessary design criteria. The evaluation is based on discussions with HFHV staff and their existing knowledge of attitudes towards sanitation in Kien Giang.

Table 3: $\quad$ List of onsite sanitation technologies from the Compendium of Sanitation Systems and Technologies and Sanitation Strategies and Technologies: Flood-prone and High Water Table Areas of Bangladesh.

\begin{tabular}{|c|c|c|c|c|c|}
\hline $\begin{array}{l}\text { Onsite Collection \& } \\
\text { Storage System }\end{array}$ & $\begin{array}{c}\text { Proven } \\
\text { and } \\
\text { Ready }\end{array}$ & $\begin{array}{c}\text { Single } \\
\text { Household }\end{array}$ & $\begin{array}{c}\text { Isolates } \\
\text { Pathogens }\end{array}$ & $\begin{array}{l}\text { Culturally } \\
\text { Acceptable }\end{array}$ & $\begin{array}{l}\text { Minimal } \\
\text { Ongoing } \\
\text { Expenses }\end{array}$ \\
\hline Urine Storage Tank & Yes & Yes & Yes & No & Yes \\
\hline Conventional Single Pit Latrine & Yes & Yes & No & No & Yes \\
\hline Single Ventilated Pit Latrine (VIP) & Yes & Yes & No & No & Yes \\
\hline Double Pit Latrine & Yes & Yes & No & No & Yes \\
\hline Borehole Latrine & Yes & Yes & No & No & Yes \\
\hline $\begin{array}{l}\text { Reed Odourless Earth Closet } \\
\text { (ROEC) }\end{array}$ & Yes & Yes & No & No & Yes \\
\hline Compost Chamber & Yes & Yes & Yes & No & Yes \\
\hline Fossa Alterna & Yes & Yes & No & No & Yes \\
\hline Double Dehydration Vault & Yes & Yes & Yes & No & Yes \\
\hline Twin Pits For Pour Flush Latrine & Yes & Yes & No & Yes & Yes \\
\hline Septic Tank & Yes & Yes & No & Yes & Yes \\
\hline Aquaprivy & Yes & Yes & No & Yes & Yes \\
\hline Anaerobic Baffled Reactor (ABR) & Yes & Yes & No & Yes & Yes \\
\hline Anaerobic Filter & Yes & Yes & No & Yes & Yes \\
\hline Anaerobic Biogas Reactor & Yes & Yes & No & Possibly & Yes \\
\hline Bucket Latrine & Yes & Yes & No & No & Yes \\
\hline Trench Latrine & Yes & Yes & No & No & Yes \\
\hline Long Drop Toilet & Yes & No & No & No & Yes \\
\hline
\end{tabular}


All of these technologies meet the first criteria listed as they have been proven in previous sanitation programmes and are ready to implement. HFHV's work centres on building housing, water and sanitation solutions for single households. As such the technology cannot be experimental, must be able to be installed immediately and be reliable in the operational phase.

All of the technologies, except the long drop, also meet the second criteria as they are appropriate for single households. Each can be installed as a standalone structure and some, such as the compost chamber, are suitable for inclusion within the housing design. The long drop toilet is designed for use in apartment buildings and so was not considered further.

The next criteria to be assessed were those relating to the Kien Giang environment and whether they isolated pathogenic material sufficiently from human contact under these conditions. The environmental conditions most affecting the choice of sanitation options are; the high watertables all year round, possible flooding and soils with high clay content. The following sections discuss each option or a group of options of similar design against the design criteria relating to the environmental conditions.

\subsection{Technologies not suitable for isolating pathogens}

\subsubsection{Pit latrine technologies}

Pit latrine technologies, such as the single pit, the single and double VIPs, the borehole latrine, the ROEC, the Fossa Alterna and the Twin Pits for Pour Flush, all rely on leaching of the liquids from the pit into the surrounding soils to both reduce the volume of the waste being treated and for treatment of the pathogenic effluent itself. These are not appropriate in isolating pathogens in high watertable environments as leaching effluent would contaminate the groundwater and, if the hydraulic gradient allows, canals that the groundwater may flow into. Seasonal flooding may also cause the pits to overflow, spreading effluent and creating contact opportunities.

Additionally due to the high water tables and clay soils the conventional installation of these technologies in the sub-surface is not appropriate. Pits will either be flooded by groundwater or clay soils will inhibit the rate of leaching, reducing the effective volume and the lifespan of the pit (ITNBangladesh, 2003).

An alternative to conventional installation is to build them wholly or partially above ground with the pit surrounded by a mound of earth into which liquids leach. The World Health Organisation (2012) recommends that pit bottoms be at least two metres above the water table. However, in the Mekong Delta with land inundation occurring during the wet season and the water table rising to or above the surface, building the pit above the surface is not practical.

\subsubsection{Anaerobic reactors}

Anaerobic reactors are the septic tank, aquaprivy, $\mathrm{ABR}$, anaerobic filter and anaerobic biogas reactor. These are all water dependent technologies in that they require water for flushing. These technologies require secondary treatment of the effluent via a leach field or evapotranspiration bed to sufficiently remove pathogens from human contact.

None of these technologies, except the anaerobic digester, are appropriate for rural Kien Giang as they are not designed to be water tight and therefore can leak pathogens into the groundwater. Once again with the groundwater sitting on or above the land surface opportunities for human contact are created.

Additionally, leach fields are not suitable for areas with high water tables as they can contaminate the groundwater, nor are they suitable in clay soils as the effluent cannot percolate into the soil fast enough, which floods the sounding soils and creates opportunities for human or disease vector contact. Simple evapotranspiration beds are not suitable in the area as they can be inundated during seasonal flood events and they pose the risk of groundwater contamination from leaching. In addition, costs may be prohibitive as they would need to be covered during the wet season.

These technologies also accumulate faecal sludge which must be emptied from the collection tank periodically. Sludge levels should be checked annually, with tanks emptied every two to five years (Tilley et al, 2008). Currently there is no infrastructure in place in Kien Giang to support the emptying of and treatment of sludge from septic tanks or similar technologies. The manual emptying of faecal sludge from septic tanks and onsite disposal poses too great a health risk and will not isolate pathogens sufficiently from human contact.

\subsubsection{Other technologies}

Bucket latrines are inappropriate as they do not provide sufficient isolation of waste from possible human contact for this project. Trench latrines are inappropriate as high watertables will flood them and they attract disease vectors, thereby spreading pathogens and creating opportunities for human contact. 


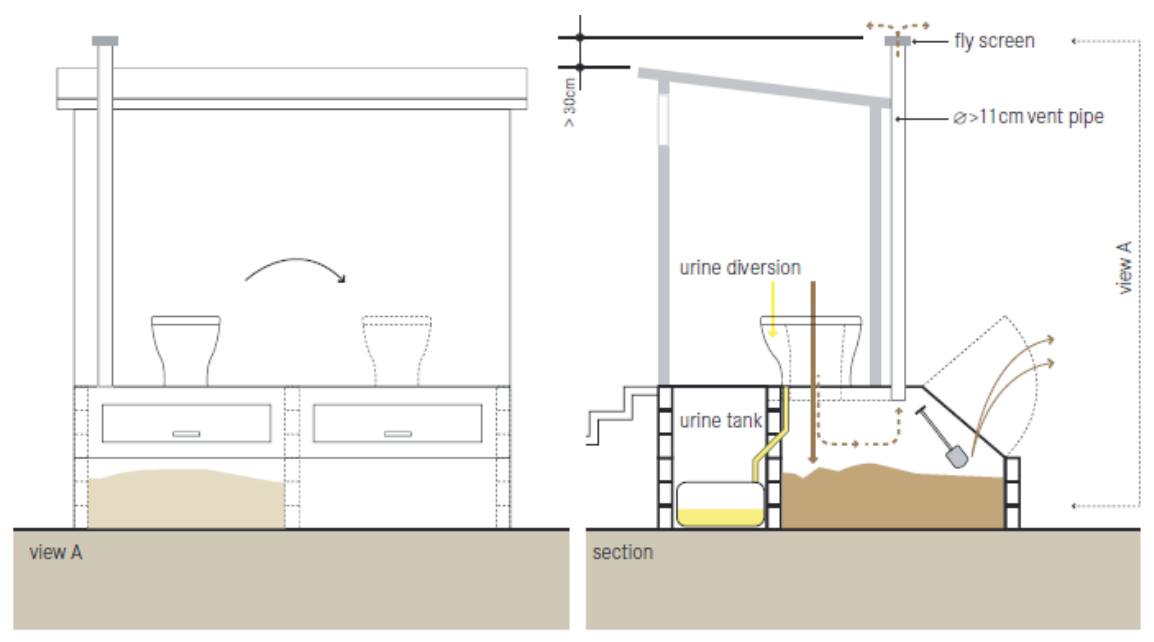

Figure 3: Double dehydration vault (Tilley et al, 2008).

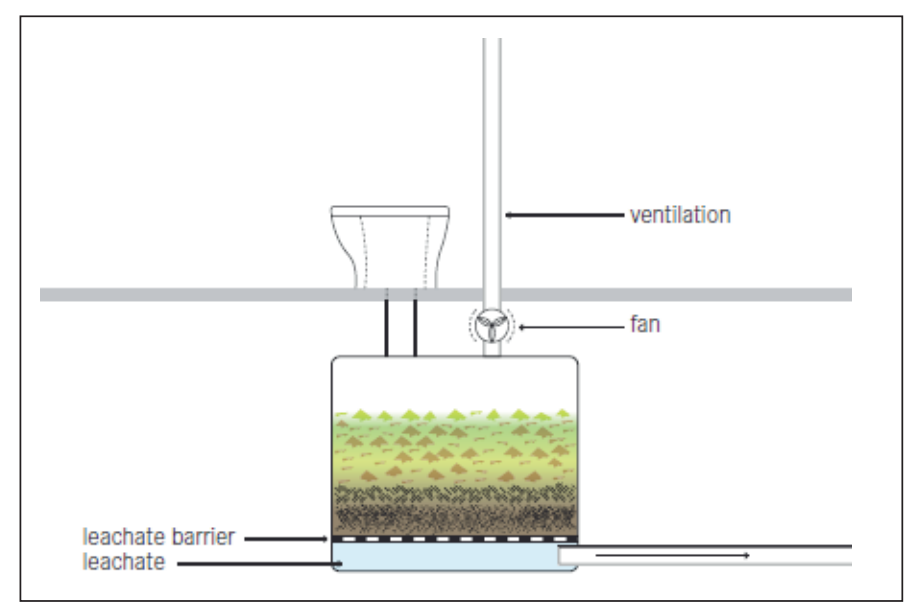

Figure 4: Composting chamber (Tilley et al, 2008).

\subsection{Technologies suitable for isolating pathogens}

\subsubsection{Urine storage tanks}

Urine storage tanks meet the criteria of isolating pathogens because "with the exception of some rare cases, urine is sterile when it leaves the body" (Tilley et al, 2008). Urine is diverted away from other waste streams at the user interface and collected into temporary small mobile storage containers made of plastic or fibreglass. These mobile containers can then be used to transport the urine to larger more permanent concrete or plastic storage containers where the urine will be stored until sanitised. The storage containers are water tight and installed above ground and are therefore appropriate for high watertable or flood prone areas.

\subsubsection{Dehydration vaults}

Dehydration vaults collect and store dry faeces (Figure 3) and provide sufficient isolation of pathogens during treatment to meet the criteria. "Two alternating vaults allow the faeces to dehydrate in one vault while the other vault fills" (Tilley et al, 2008). Treatment relies on time and dehydration of faecal matter. Dehydration deprives the pathogens of the moisture they need to survive. Urine, anal cleansing water and hand wash water are all diverted to other collection facilities to allow dehydration to occur. Dry faeces are stored for a minimum of six months before being removed from the vault for disposal or use. Anal cleansing water can be collected and treated onsite with a small evapotranspiration bed built into the side of the structure.

Dehydration vaults are constructed above ground and to be watertight, and therefore are suitable for flood prone areas and those with high watertables as pathogens will be contained and will not be spread by floodwaters.

\subsubsection{Composting chambers}

The composting chamber can be designed in various configurations and be installed above or below ground. This technology has a high pathogen reduction rate (Tilley et al, 2008) and destroys them with the heat generated during the composting process and over time in a hostile environment. The 
resulting compost is safe to handle and can be utilised as a soil improver (Tilley et al, 2008).

The system does not rely on leaching into the surrounding soil to dispose of liquids but instead has a leachate collection system. The leachate can be disposed of in a small evapotranspiration bed built into the side of the structure. Anal cleansing water should not be added to the composting chamber as it may create foul smelling anaerobic conditions and can be diverted and disposed of in the same evaporation bed as the leachate.

\subsubsection{Other criteria}

The handling and disposal of human waste onsite is not culturally acceptable in southern Vietnam. Therefore even though urine collection tanks, dehydration vaults and composting chambers meet the previous criteria, they do not meet the criterion of cultural acceptance. Despite the difficulties in obtaining cultural acceptance, these technologies should be considered as an option for households in Kien Giang. "Dry and composting toilets ought to be advocated wherever they are useful and affordable" (Black \& Fawcett, 2008, p132).

Putting aside their unsuitability for the previous criteria, HFHV have advised that pit latrine technologies are also not culturally acceptable as they do not have sufficient status and can be seen as technologically deficient and odourous.

Pour-flush technologies are culturally acceptable as these create a water seal that is seen as hygienic and technologically sound according to HFHV. Therefore, water dependent anaerobic reactors are culturally appropriate. There may be some question as to whether the use of anaerobic digester biogas would be culturally acceptable for use in the household.

The other technologies, the bucket and trench latrines, are not acceptable technologies for HFHV as they do not sufficiently separate pathogens from human contact and are not desirable for installation in the home.

Most of these technologies have low operating costs if manual emptying and onsite disposal is appropriate. For the anaerobic reactors where manual emptying is not recommended, operating costs increase with the cost of having sludge pumped out of the tanks.

As all of the options are simple technologies, each can meet the criteria of being able to be built with locally available materials. Apart from the long drop which does not apply to individual households and the bucket latrine and trench latrine which HFHV do not think are appropriate, all of the options can be adapted into HFHV's sanitation program. Many may not be suitable for areas with high water tables but HFHV also works in other areas in Vietnam where this may not be of concern. Each option should be evaluated for local conditions.

Lastly, these technologies are designed to be low cost and therefore most can be built for US\$300 or less. This is the current cost of HFHV's septic tank. The exceptions to this may be the ABR, the anaerobic filter and the anaerobic biogas reactor which are more complicated versions of the septic tank and therefore may be more expensive. The cost of a toilet will vary greatly depending on the materials used for the superstructure.

\subsection{Offsite treatment options}

As previously mentioned, offsite sanitation treatment systems are not applicable to HFHV's programmes as it does not build them. However, due to the limited options available for onsite sanitation systems, existing use of septic tanks and possible low uptake of onsite disposal systems from social and cultural concerns, it was determined that it was worth investigating and discussing a possible scenario for a decentralised treatment option. It was found that the most appropriate offsite treatment would be a co-composting facility.

"Co-composting is the controlled aerobic degradation of organics using more than one feedstock (faecal sludge and organic solid waste)" (Tilley et al, 2008). Co-composting in boxes was selected for a conceptual design using Van Khanh Commune in the South West of Kien Giang for the discussion. Box composting was selected as it is a simple process when compared to other types of composting and requires less space than windrow composting. The feasibility of a cocomposting facility will greatly depend on the cost of transportation of waste against the income that can be generated from fees and sale of the compost.

\section{CONCLUSIONS \& RECOMMENDATIONS}

The high water table and clay soils of rural Kien Giang limit the sanitation technologies appropriate for use in most of the region. Pit latrine technologies are not appropriate as high watertables will cause the pits to flood with groundwater or be inundated in annual floods creating the potential for pathogen exposure. Anaerobic reactor systems that produce pathogenic effluent and sludge are also inappropriate as high watertables and the risk of flooding negate secondary treatment options for the effluent and there is currently no means of safely disposing of the sludge. Appropriate technologies are the composting chamber, the double dehydration vault and the urine collection tank. Of these the double dehydration vault is seen as the preferred option. However, it may be difficult for these technologies to be accepted on a cultural basis. 
It is recommended that a design for both the double dehydration vault and composting chamber be developed for use in HFHV's construction programmes in Kien Giang. These technologies can also be utilised in other areas where high watertables and flooding occur. A further recommendation would be an investigation into the feasibility of a co-composting facility in rural areas.

\section{ACKNOWLEDGEMENTS}

I would like to thank Mr Giang Nguyen Truong, the construction engineer at HFHV, for answering my questions relating to this project. And more recently Jacqui Bell, the EWB in-country volunteer working with HFHV. Additionally, I would like to thank the rest of the staff in the Rach Gia office who provided so much support during my time in Kien Giang.

I would like to acknowledge the work of the Swiss Federal Institute of Aquatic Science and Technology (EAWAG), WaterAid Nepal and Deutsche Gesellschaft Internationale Zusammenarbeit (GIZ). Without their resources this project would have been a lot harder.

\section{REFERENCES}

Black, Maggie \& Fawcett, Ben, 2008, The Last Taboo, Opening the Door on the Global Sanitation Crisis, Earthscan, London U.K.

HFHVa, 2012, Annual Rainfall and Relative Humidity Data Rach Gia Station, accessed 08 March 2012 http://www.ewb.org.au/explore/initiatives/ ewbchallenge/hfhewbchallenge.

$\mathrm{HFHVb}, 2012$, Sanitation and Hygiene, accessed 21 March 2012, http://www.ewb.org.au/explore/ initiatives / ewbchallenge/hfhewbchallenge/ hfhwash.

IFS-UTS, 2011, Vietnam Water, Sanitation and Hygiene Sector Brief, prepared for AusAID by the Institute for Sustainable Futures, University of Technology Sydney, accessed 12th March 2012, http:/ / www.isf. uts.edu.au/pdfs/ISF_VietnamWASH.pdf.

ITN-Bangladesh, 2003, Sanitation Strategies and Technologies Flood-Prone and High Water Table Areas of Bangladesh, ITN-Bangladesh, Dhaka, Bangladesh.

Le, Phat Quoi, 2011, Vegetation Cover in Kien Giang Province, viewed 10 March 2012, http:// kiengiangbiospherereserve.com.vn/project/ uploads/doc/quoi_report_kgbr_landcover_2009_ en.pdf.

Mackay, Peter \& Russell, Michael, 2011, Socialist Republic of Vietnam: Climate change Impact and Adaptation Study in the Mekong Delta, viewed 27 November 2012,http:/ /www2.adb.org/Documents/ Reports/Consultant/VIE/43295/43295-012-vietacr-02.pdf.

Tilley, Elisabeth et al, 2008, Compendium of Sanitation Systems and Technologies, Swiss Federal Institute of Aquatic Science and Technology (EAWAG), Dubendorf, Switzerland.

WHO, 2010, WHO/UNICEF Joint monitoring Report 2010: Progress on Sanitation and Drinking Water, viewed 24 April 2012, http://www.who.int/ water_sanitation_health/monitoring/fast_facts / en/index.html.

WHO, 2012, Fact Sheet 3.4 Simple Pit Latrines, accessed 22 May 2012, http:/ / www.who.int/water_ sanitation_health/hygiene/emergencies/fs3_4.pdf. 